\title{
The Economic Relations between China and Thailand under the Context of CAFTA: An Assessment
}

\author{
Shen Hongfang \\ Research School of Southeast Asian Studies/Faculty of International Relations/ \\ Center of Southeast Asian Studies, Xiamen University, Xiamen, China \\ Email: hfshen@xmu.edu.cn
}

Received November $9^{\text {th }}, 2012$; revised December $9^{\text {th }}, 2012$; accepted December $16^{\text {th }}, 2012$

\begin{abstract}
The bilateral economic relations between China and Thailand have unprecedentedly increased since the signing of China-ASEAN Free Trade Agreement (CAFTA). This paper describes the rapid economic relations between China and Thailand from the perspectives of bilateral trade and investment as well as other forms of economic cooperation within the latest one decade, and elaborates the spectacular features of Sino-Thai bilateral economic ties in comparison with ASEAN as a whole and the other ASEAN member countries. In addition to explore the driving factors in boosting these two countries' economic relations, the paper also explores the problems that exists since the two countries' economic exchanges are as matter of fact under a framework of "South to South" type that embrace inevitably the week pointes such as lacking of complementarities and the others, the effect of free trade pact of "earlier heaviest" concluded by Sino-Thai government since 2003 as an experimental arrangement of CAFTA will be revaluated.
\end{abstract}

Keywords: Sino-Thai Economic Relations; CAFTA; Assessment

\section{Introduction}

The last decade has witnessed rapid expansion of Sino-Thai bilateral economic relations which was unprecedented in the history of economic exchanges between the two countries ascribing to the signing of China-ASEAN Free Trade Agreement (CAFTA). The three agreements signed attaching to CAFTA have been the driving forces to the expansion of the two countries' economic exchanges, namely, the Agreements on Trade in Goods, the Agreement on Trade in Services, and ASEANChina Investment Agreement which were signed on 2004, 2007 and 2009 separately.

Owing to the multifarious positive factors, Thailand has become one of most active participants among the other ASEAN member countries to take advantage of this free trade deal, even though the country has been undergoing political instability since Thaksin was overthrown by coup in September 2006. In addition to follow the normal schedule of tariff reduction of CAFTA, Thai government signed with Chinese government an agreement on accelerating tariff elimination under the Early Harvest programme over a two-year period, and to be continued afterward. Although "earlier harvest" of CAFTA has caused some problems to the farmers of both sides, the Thai government is still firmly committed to the deal. It has formed a joint working group with China to survey the problems and obstacles in importing and exporting agro-products of the two countries. Thai Minister of Agriculture and Cooperation signed with China's General Administration of Quality Supervision a memorandum of understanding (MOU) in November 2009 with an aim to provide more opportunities for traders in the two countries to market their farm products ${ }^{1}$. The expansion of free

${ }^{1}$ Thai-Chinese Trade in Agricultural Goods Contributing to Economic Relations between ASEAN and China, (23/12/2009)

http://thailand.prd.go.th/view_inside.php?id=4655. market access of agro-products between the two countries has been merited as "WTO-plus"2.

In addition to the booming trade, mutual investment of both sides is growing in a fast space, especially with the increasing flow of Chinese investment into Thailand, the model of "twoway" investment is coming into being. Some other types of economic cooperation, such as tourist cooperation and trade in service as well as financial cooperation (or coordination) are also vital to Sino-Thai bilateral economic growth and development.

Complex driving forces and multifarious factors are contributing to the gaining momentum of China's growing economic contacts with Thailand, such as the governments' supporting measures. The two governments have set up clear policies to strengthen their bilateral ties. Many joint meetings of highranking trade representatives of the two countries were being organized in exploration of market access of both sides. Meanwhile, trade exhibitions for Thai products have also been held in many cities and places in China. Moreover, the closing ties between prominent personalities and institutions of the two countries play also an important role in promoting the bilateral economic exchanges. The signing of the second five-year Joint Action Plan on Thailand-China Strategic Cooperation for 20122016, the Memorandum of Understanding (MOU) on Agricultural Trade Cooperation, and a five-year development plan for 2012-2016 under the Agreement on Expanding and Deepening Bilateral Economic and Trade Cooperation during Thai Prime Minister Yingluck Shinawatra's visit to China from 17 to 19 April 2012 will be no doubt driving forces to the two countries' economic expansion.

Nevertheless, since the two countries' economic exchanges

\footnotetext{
${ }^{2}$ To achieve free trade of agro-products in WTO is very difficult, since it relates to the interests of the majority of farmers.
} 
are as matter of fact under a framework of "South to South" type that embrace inevitably the week pointes such as lacking of complementarities ascribing to the major import and export commodities are overlapped though the overall value of the bilateral trade are expanding. Besides, the figures of Thai direct investment to China in this one decade is appearing smaller in comparison to that of Singapore, Malaysia, Indonesia and Philippines for some complicated reasons.

This paper is divided into four sections. Section 1 is the introduction of the whole paper. Section 2 describes the overall situation of Sino-Thai economic relations in the latest one decade from the perspectives of bilateral trade and investment as well as other forms of economic cooperation under the CAFTA, and elaborates the spectacular features of Sino-Thai bilateral economic ties in comparison with ASEAN as a whole and the other ASEAN member countries. Section 3 explores the driving forces and positive factors in boosting the expansion of these two countries' bilateral economic relations, and in particular, the efforts of the two governments in promoting trading of agro-products as an experimental arrangement of CAFTA will be under evaluated, and the major policies and measures adopted by both sides are elaborated. Section 4 explores the problems that have existed in the course of economic interchange, for example, some overlapped key import and export commodities caused less complementarity but strong competitiveness in the both domestic markets and even international markets will be mentioned, and the major constraints in impeding the bilateral direct investment are also quest. Simultaneously, it predict future trend of the two countries' economic relations under the development of CAFTA and encouraged by the Chinese and Thai official and non-official sectors.

\section{Overall Situation of Sino-Thai Economic Relations under the CAFTA and the Features}

The 21 st century has witnessed significant expansion of Sino-Thai bilateral economic relations that extended from trade in goods and to trade in service, mutual investment and financial coordination as well as the other forms of economic cooperation, despite changes in the international situation and their own domestic conditions.

\section{Trade in Goods Has Greatly Increased and the Structures of Imports and Exports Have Diversified}

\section{Trade in Goods Has Greatly Increased under CAFTA}

According to China's official figures, the trend of bilateral trade in goods between China and Thailand from 2002 to 2011 have been keeping a momentum of up growing even though the Kingdom of Thailand has undergone in one time and another the political disturbance.

Table 1 shows that the total value of yearly bilateral trade in goods of the two countries has expanded substantially from US \$85.61hundred million in 2002 to US \$577.9 hundred mil- lion in 2011, with an increase of almost 6.75 folds within al- most one decade. Although global economic recession rooted from American mitigated crisis affected heavily the trade in value of the two countries in 2009 that caused shrinkage by $7.24 \%$ on the year, it restore in the following year with growth rate of $38.73 \%$, reaching to US $\$ 529.56$ hundred million. The overall value of bilateral trade has continued to grow in 2011, reached to US $\$ 577$ hundred million, a growth rate of $9.13 \%$.
The trade expansion of the two countries under the CAFTA has been over speed in comparison with the trade between China and ASEAN as a whole except the year of 2007, 2009 and 2011. China ranked second after the Japan in Thai's trading partners according to Thai Customs statistics of 2011, and China is Thailand's largest export market and second-largest source of imports, and Thailand has ranked 15th in China's foreign trade partners owing mostly by the "zero tariff" preferential policies related to CAFTA have effectively boosted the trade between China and Thailand ${ }^{3}$.

Table 2 shows that Thailand enjoys trade surplus in from 2001-2010 according to Chinese figures. Along with the expanding of Sino-Thai bilateral trade, the value of trade surplus on the side of Thailand is also increasing from US \$2.38 billion in 2001 to US $\$ 13.45$ billion in 2010 . Thailand was locked only in a trade deficit with China amounting to US $\$ 3.52$ billion in 2011, while exports from Thailand to China were US $\$ 27.13$ billion, and imports were US $\$ 30.66$ billion $^{4}$. However, the revised figure of the overall trade value of the two countries amounted to US $\$ 64.7$ billion for $2011^{5}$.

\section{The Structures of Imports and Exports of Both Countries Have Diversified}

Affected by the deepening of "intra-product specialization" led particularly by MNCs and TNEs under economic globalizetion and regionalization, the trade structures of China and Thailand have undergone tremendous changes for the latest decade characterizing with machinery, intra-industrial goods containing electronic products, parts and intermediate goods as the major exports and imports. In other word, a large part of trade in PCAs (parts, components and accessories) is of the intra-firm variety that constitutes the major part of the foreign trade of the two countries.

Whereas, the trade structures between China and Thailand have manifested particularities for not only diversifying, but also overlapped with the feature of horizontal division of labor that have diverted from the old pattern that agriculture-based products constituted the major part of China's imports from Thailand, while textiles and garments, iron and steel products and chemical products were China's major exports to Thailand ${ }^{6}$.

In 2010, Thai Customs figures showed that top 9 export products valued over US $\$ 5$ hundred million from Thailand to China that constituted $73.5 \%$ of Thai export trade value to China were Automatic data processing equipment and parts, Natural rubber, Chemical products, Plastic products, Rubber products, Cassava products, Refined oil, Electronic integrated circuits, and Wood and wooden products. At the same time, there were 13 import products from China to Thailand that over

\footnotetext{
${ }^{3}$ The revised figure showed that the trade value of the two countries hit 64.7 billion US dollars in 2011. China Daily/Asia News Network: China, Thailand enhance strategic relationship.April 18, 2012.

http://news.asiaone.com/News/AsiaOne\%2BNews/Asia/Story/hA1Story201 20418-340515.html.

${ }^{4}$ http://countryreport.mofcom.gov.cn/record/view110209.asp?news_id=277 51 .

${ }^{5}$ The government Public Relations Department.

http://thailand.prd.go.th/view_news.php?id=6243\&a=2

${ }^{6}$ During the pre-crisis period of 1988-1996, Thailand's proportion of agricultural exports to its total exports to China stood between 48 and 71 percent. Sompop Manarungsan, Thailand-China Cooperation in Trade, Investment and official Development Assistance, p. 296. http://www.ide.go.jp/English/Publish/Download/Brc/pdf/01_thailandandchi na.pdf.
} 
SHEN H. F.

Table 1.

Sino-thai bilateral trade in comparison with trade of sino-ASEAN* (Value: hundred million US \$).

\begin{tabular}{cccccc}
\hline Year & $\begin{array}{c}\text { Total trade value of China } \\
\text { and Thailand }\end{array}$ & Growth (\%) & $\begin{array}{c}\text { Total trade value of China } \\
\text { and ASEAN }\end{array}$ & Growth (\%) & $\begin{array}{c}\text { In China and ASEAN } \\
\text { trade (\%) }\end{array}$ \\
\hline 2002 & 85.61 & - & 547.67 & - & 15.63 \\
2003 & 126.55 & 47.82 & 782.52 & 42.88 & 16.17 \\
2004 & 173.43 & 37.04 & 1058.80 & 35.31 & 16.38 \\
2005 & 218.12 & 25.77 & 1303.70 & 23.13 & 16.73 \\
2006 & 277.27 & 27.12 & 1608.40 & 23.37 & 17.24 \\
2007 & 346.38 & 24.93 & 2025.08 & 25.91 & 17.10 \\
2008 & 411.53 & 19.10 & 2311.17 & 14.13 & 17.85 \\
2009 & 381.70 & -7.24 & 2130.11 & -7.8 & 17.92 \\
2010 & 529.56 & 38.73 & 2927.76 & 37.45 & 18.08 \\
$2011^{* *}$ & 577.90 & 9.13 & 3628.50 & 23.93 & 15.93 \\
\hline
\end{tabular}

Note: "This table is constructed by author; ${ }^{* *}$ Preliminary figure; Sources: Statistics are from Thai Ministry of Commerce, Thai Customs and China Customs. Source: Economic and Commercial Counselor's Office of the Embassy of the People's Republic of China in the Kingdom of Thailand, "Sino-Thai Economic and Trade Cooperation 2011" http://th.mofcom.gov.cn/aarticle/zxhz/hzjj/201111/20111107835309.html; Wang Yu-zhu, The Impact of CAFTA on China-ASEAN Relationship: An Evaluation from Strategic perspective, Southeast Asian Affairs No.1, 2012.

Table 2.

Trade figures of China and Thailand (2001-2011) (Value: hundred million US \$).

\begin{tabular}{|c|c|c|c|c|c|c|c|}
\hline Year & Total & Growth (\%) & Export & Growth (\%) & Import & Growth (\%) & Balance \\
\hline 2001 & 70.5 & 6.4 & 23.4 & 4.2 & 47.1 & 7.6 & -23.8 \\
\hline 2002 & 85.6 & 21.4 & 29.6 & 26.6 & 56.0 & 18.9 & -26.5 \\
\hline 2003 & 126.6 & 47.8 & 38.3 & 29.4 & 88.3 & 57.5 & -50.0 \\
\hline 2004 & 173.4 & 37.0 & 58.0 & 51.6 & 115.4 & 30.7 & -57.4 \\
\hline 2005 & 218.1 & 25.8 & 78.2 & 34.8 & 139.9 & 21.2 & -61.7 \\
\hline 2006 & 277.3 & 27.1 & 97.6 & 24.9 & 179.6 & 28.4 & -82.0 \\
\hline 2007 & 346.4 & 24.9 & 119.7 & 22.6 & 226.6 & 26.2 & -101.0 \\
\hline 2008 & 411.5 & 19.1 & 155.2 & 30.3 & 256.3 & 13.2 & -101.1 \\
\hline 2009 & 381.7 & -7.4 & 133.2 & -14.7 & 248.5 & -2.9 & -115.2 \\
\hline 2010 & 529.6 & 38.7 & 197.6 & 48.3 & 332.0 & 33.6 & -134.5 \\
\hline $2011^{*}$ & 577.9 & 9.1 & 306.6 & 54.9 & $273 . .1$ & -17.8 & 33.5 \\
\hline
\end{tabular}

Note: *Preliminary figure; Source: Statistics from 2001 to 2010 from China Customs, cited from "Sino-Thai Economic and Trade Cooperation 2011 " from website of Economic and Commercial Counselor's Office of the Embassy of the People's Republic of China in the Kingdom of Thailand. November 17, 2011.

http://th.mofcom.gov.cn/aarticle/zxhz/hzjj/201111/20111107835309.html; 2011 figure from Thai government Public Relations Department. http://thailand.prd.go.th/view_news.php?id=6243\&a=2.

the value of US $\$ 5$ hundred million. These were Computer equipment and parts, Electrical equipment and spare parts, Household appliances, Mechanical equipment and spare parts, Chemical products, Iron and steel products, A variety of machine manufactured goods, Textile, Electronic integrated circuits, Metal products, Other metal ore and base metal products, Fertilizer and pesticides, Plastic products. All these 13 categories of products constituted overall value of $74.6 \%$ of Thai's imports from China ${ }^{7}$.

Tables 3 and $\mathbf{4}$ listed "top 10" import and exports products of the two countries with an aim to have a better understanding the structures of trade in goods of the two countries.

The spectacular characteristics of Sino-Thai bilateral trade which is differed from that between China and ASEAN other member countries is that the trade of agro-products has been greatly expanding contributing to the signing of the Early Har-

${ }^{7}$ http://www.mofcom.gov.cn/aarticle/i/dxfw/cj/201105/20110507556587.ht $\mathrm{m}$. vest Agreement between Thai government and Chinese government in January 2004. In addition to follow the normal schedule of tariff reduction of CAFTA, the Early Harvest program has accelerated tariff elimination und over a two-year period that embrace fruits and vegetables lines of products under the customs tariff schedule code of 07 and 08 that include live animals, meat and other edible animal parts, fish products, dairy products, fowl eggs, live trees, vegetables and fruit, and edible nuts. The two countries had also agreed to accelerate tariff reduction on two addition products, anthracite and coal residue. This process began in January 2004 and by January of 2006, and to be continued afterward ${ }^{8}$.

Since then, both sides have a great access of agro-products to

${ }^{8}$ Agreement between the Government of the Kingdom of Thailand and the People's Republic of China on Accelerated Tariff Elimination under the Early harvest of the Programme of the Framework Agreement on Comprehensive Economic Cooperation between ASEAN and China. http://www.aseansec.org. 
Table 3.

Ten major exports of Thailand to China, 2010 (Value: hundred million US \$).

\begin{tabular}{ccc}
\hline Items & Value & Growth \\
\hline Automatic data processing equipment and parts & 50.37 & 16.40 \\
Natural rubber & 24.46 & 57.4 \\
Chemical products & 17.90 & 31.7 \\
Ethylene and other polymers & 16.32 & 50.8 \\
Rubber products & 14.12 & 80.12 \\
Cassava products & 11.56 & 46.2 \\
Refined oil & 8.59 & 29.2 \\
Electronic integrated circuits & 8.07 & 9.72 \\
Wood and wooden products & 6.43 & 60.01 \\
Other electrical equipment, components & 4.75 & 41.59 \\
\hline
\end{tabular}

Source: Thai Ministry of Commerce, cited from "Sino-Thai Economic and Trade Cooperation 2011" from website of Economic and Commercial Counselor's Office of the Embassy of the People's Republic of China in the Kingdom of Thailand. November 17, 2011.

http://th.mofcom.gov.cn/aarticle/zxhz/hzjj/201111/20111107835309.html.

Table 4.

Ten major imports Thailand from China, 2010 (Value: hundred million US \$).

\begin{tabular}{ccc}
\hline Items & Value & Growth \\
\hline Computer equipment and parts & 33.70 & 22.2 \\
Electrical equipment and spare parts & 32.20 & 31.5 \\
Household appliances & 21.42 & 30.0 \\
Mechanical equipment and spare parts & 21.37 & 53.4 \\
Chemical products & 16.82 & 47.0 \\
Iron and steel products & 10.50 & 129.7 \\
manufactured goods & 7.93 & 37.6 \\
Textile & 7.85 & 47.6 \\
Electronic integrated circuits & 6.44 & 85.8 \\
Metal products & 6.38 & 34.5 \\
\hline
\end{tabular}

Sources: same as Table 3.

their counterpart markets. Presently, Thailand has become China's ninth largest import source for agricultural products, and tenth largest export market of China's agricultural products. The overall trade value of agro-products of the two countries increased 4.8 folds in 10 years, reached to US $\$ 3.68$ billion, and the average annual growth rate is $21.5 \%{ }^{9}$. Thai rice and fruits are well known to the Chinese citizens and become their favorites. Table 5 provides the information that the export value of four major Thai original products to China's market within a decade from 2001 to 2010 have greatly increased.

It has all the reasons to trust that Sino-Thai bilateral trade will continue to grow into a higher level as the two countries has signed joint action plan of strategic cooperation and the

${ }^{9}$ Total trade value of agro-products of China and Thailand increased by 5 folds within ten years. 17 Februry, 2012. http://www.caexpo.org. five-year plan of expanding trade and economic cooperation during Thai Prime Minister Yingluck Shinawatra's visit to China from April 17-20, 2012. The Chinese premier Wen Jiabao proposed expanding bilateral trade to 100 billion US dollars annually before 2015 and enhancing cooperation in ocean, telecommunication, technology, energy and agriculture ${ }^{10}$.

Chinese President $\mathrm{Hu}$ Jintao also urged the two sides to observe the guidance of the newly signed joint action plan of strategic cooperation and the five-year plan of expanding trade and economic cooperation when he met Thai Prime Minister Yingluck Shinawatra in the Great Hall of the People on April $18,2012^{11}$. Both sides pledged to boost bilateral cooperation in light of the poor state of the global economy and signed a series of deals covering, among other sectors, agriculture and transport and elevated relations to a comprehensive strategic partnership.

\section{Mutual Investment Is Becoming the Main Component of Sino-Thai Bilateral Economic Cooperation}

In addition to the booming of the bilateral trade, cross investment of the two countries has also become the main component of bilateral economic cooperation in spite of Thailand was being affected by the 1997 financial crisis for about five years till 2002, and both sides have undergone some other tortures such as the avian flu in 2003, the global economic slump in 2005 and world economic recession caused by US subprime mortgage crisis since 2007.

According to China's official data, there were 4015 investment projects proposed by Thai companies to invest China with the total value of about US $\$ 9.8$ billion. However, the utilized, or paid-up capital reached 3.29 billion in US \$ only under the various incentives provided by Chinese Central and Provincial governments by from the year of 2000-2010 ${ }^{12}$. Table 6 demonstrates the situation of Thai investment in China that unfortunately in a state of up and down affected mostly by economic and non-economic factors. Furthermore, Thai investment to China is smaller if compare with the investments of the other old ASEAN member countries' to China. The figures provided by China's Ministry of Commerce have indicated that Singapore companies have put in US $\$ 24.38$ billions investment in China within a half and six years from 2005 to the end of 2011; Malaysia, US \$2.36 billion; Philippines US \$9.5 hundred million, and Indonesia US \$7 hundred million, that all surpassed that US $\$ 6.3$ hundred million of Thai investment to China in the same period ${ }^{13}$.

Most Thai investors are investing China's small and medium scale projects, only a few big companies are investing some more important China's projects ${ }^{14}$. Areas of investment ranging from agribusiness and agro industries, hydro electrical and coal

\footnotetext{
${ }^{10}$ According to China's Xinhua news report, the two premiers witnessed the sealing of seven bilateral cooperation agreements on issues ranging from trade, agriculture and railways to flood and drought prevention and ocean research. Xinhua news report, China, Thailand upgrade bilateral ties, vow closer trade links. April 17, 2012.

http://news.xinhuanet.com/english/china/2012-04/18/c_131533612.htm.

${ }^{11}$ People's Daily Online. Chinese president demands stronger Thailand ties (Xinhua), April 19, 2012 http://english.people.com.cn/102774/7791797.html ${ }^{12} \mathrm{http}: / /$ th.china-embassy.org/chn ztgx/gxgk/t86119.htm/.

${ }^{13}$ China's Ministry of Commerce.Cited from Wang Yu-zhu, Table 1. P.13.

${ }^{14}$ Namely, the CP group, Saha-union group, Kasetrungrueng Co., Lid., Cement Thai Group, Katingdaeng (Red Gore)group, Bangkok Bank Co., Ltd., Thai Farmer bank (Kasikorn Bank), M-Thai group, Mitphol Group, and Central Group.
} 
SHEN H. F.

Table 5.

Thai major original products to China's market, 2001-2010 (Value: hundred million US \$).

\begin{tabular}{cccccccccccc}
\hline Items & 2001 & 2002 & 2003 & 2004 & 2005 & 2006 & 2007 & 2008 & 2009 & 2010 \\
\hline Rubber & 2.72 & 3.58 & 7.16 & 7.85 & 8.15 & 13.54 & 15.91 & 19.38 & 15.56 & 24.46 \\
Cassava & 1.23 & 1.38 & 1.69 & 2.82 & 3.83 & 5.30 & 4.72 & 3.39 & 7.91 & 11.56 \\
Rice & 0.82 & 1.04 & 0.98 & 2.25 & 1.93 & 2.75 & 2.16 & 1.60 & 2.11 & 2.23 \\
Fruits & 0.31 & 0.35 & 0.69 & 0.73 & 0.97 & 0.98 & 1.28 & 1.51 & 2.0 & 2.03 \\
\hline
\end{tabular}

Sources: same as Table 3.

Table 6.

Thai investments in China, 2000-2010 (Value: ten thousand US \$).

\begin{tabular}{ccccc}
\hline Year & No. of projects & Growth (\%) & Utilized capital & Growth (\%) \\
\hline 2000 & 130 & 9.24 & 20357 & 37.25 \\
2001 & 140 & 7.69 & 19421 & -4.6 \\
2002 & 161 & 15 & 18772 & -3.34 \\
2003 & 194 & 20.5 & 17352 & -7.56 \\
2004 & 162 & -16.49 & 17868 & 2.97 \\
2005 & 147 & -9.26 & 9590 & -46.33 \\
2006 & 108 & -26.53 & 14860 & 54.95 \\
2007 & 79 & -26.85 & 8948 & -39.78 \\
2008 & 56 & -29.11 & 12921 & 44.4 \\
2009 & 48 & -14.29 & 4866 & -62.34 \\
2010 & 40 & -16.7 & 5134 & 5.5 \\
\hline
\end{tabular}

Sources: China's Ministry of Commerce. Cited from website of Economic and Commercial Counselor's Office of the Embassy of the People's Republic of China in the Kingdom of Thailand. November 17, 2011.

http://th.mofcom.gov.cn/aarticle/zxhz/hzjj/201111/20111107835309.html.

power generation, brewery, cosmetics, motorcycles and auto parts, commercial banking, retail-trade, hotel and restaurants, sports activities (i.e. the golf course), real estate and trading.

Chinese investment to Thailand in this first decade of $21 \mathrm{st}$ century is also not very smooth, with the lowest in 2005 for only US $\$ 4.77$ million, but highest in 2007 of US \$76.41 million, and the rest of the years were tramped. Chinese figures show that Chinese investments to Thailand were US \$57.31 million in 2003; US \$23.43 million in 2004; US \$4.77 million in 2005; US \$15.84 million in 2006; US \$76.41 million in 2007; US $\$ 45.47$ million in 2008; US $\$ 49.77$ million in 2009 and US $\$ 6.9987$ billion in 2010 .

Taking into account that Chinese enterprises, both stateowned and private have made a great stride in investing Southeast Asia under the encouragement of "going out" policy of the Chinese government, the Chinese investment in Thailand did not increased but dropped significantly after 2003, hence, the proportion of which has been also reducing, and dropped even to $1.84 \%$ in the total in 2008 and 2009 . The major constraints of bilateral investment will be discussed in next section. The situation changed in 2010 however, the year witnessed the renewing momentum of Chinese investment to Thailand while the Chinese FDI overseas to the world has achieved unprecedented increase when China's enterprises have seized the op- portunity of the picking up of world economy. China's official statistics showed that China's FDI to Thailand of that year was 7 hundred million US\$, that enable Thailand to rank No. eleven among the other twenty biggest destinations for China's outward investment in the year ${ }^{15}$.

Chinese investments in Thailand are generally in a form of joint ventures, and investing in the field of agriculture and agro-industries, bio-fuel or alternative energy production, mineral and ceramics, textiles and garments, metal products and machinery. The major Chinese companies in Thailand are: The Worldbest Group investing in Thai textile raw material production, final textile products and citric acid for industrial uses under the "DICA" brand; Haier Group, in joint venture with Local Thai partners, the Di-star Company to produce electrical appliance; TCL Corporation set up factories in Thailand to produce audio-visual equipment; Huawei Technology Corp. invest Thailand with the local companies by doing different projects of cellular-network construction, or communications network of CAT and the others. (Sompop, 2009: pp. 326-332).

\section{Other Forms of Economic Cooperation Are Vital to Sino-Thai Bilateral Relations}

The expansion of economic relations between China and Thailand can be seen not only with respect to trade in goods and investment, but also in other forms, including tourist cooperation, trade in service and financial coordination.

China and Thailand share the common ground for cooperation between their tourism sectors, and both countries are reciprocally the source market of the other since the effect of the linkage of the tourist industry to economic expansion has been recognized as an engine for economic growth. With the rapid increase of Chinese living standard, more and more Chinese people are going abroad to spend their vocation. With an aim to abstract more Chinese to come, Thai government adopted many effect actions. In addition to improve soft and hard ware of domestic facilities including to improve the quality of domestic tourist-related service sector, and to work on diversifying Thai tourism industry so that tourists can enjoy cultural excursions while, at the same time, being able to pursue other activities like spas, sports, medical check-ups and eco-tourism.

In addition, The Tourism Authority of Thailand has been working closely with the Thai-Chinese Tourism Association and the Chinese private sector to promote quality tourism according to the Royal Decree on Tour Operators and Tour Guides 2008 and also the Chinese government's new regulations on tour operators and travel agents. Over one million tourists from China visit Thailand since 2006. In 2007, the

\footnotetext{
${ }^{15}$ http://hzs.mofcom.gov.cn/aarticle/date/201109/20110907741156.
} 
number of Chinese tourists was the fourth largest in terms of international visitors to Thailand.

Affected by global economic recession, Thai political instability, and severe flood followed, Thailand has experienced a drop in the number of Chinese tourists. In order to abstract more foreign visitors, including Chinese tourist, Thai government has already undertaken several measures, such as the waiving of visa fees which was effective from March to June 2009 and later extending it until March 2010; reducing take-off and landing charges for aircrafts; and lowering the entrance fees for Thai national parks by 50 percent.

Moreover, to ensure safety and provide Chinese tourists with peace of mind, and to protest their interests, Thai Cabinet approved a scheme to provide travel insurance for Chinese tourists in case of unexpected events. The tourist attractions of the local governments and agencies will also improve the relevant laws and regulations, and to set up a special committee to help solve unexpected problems, a 24-hour alarm Telephone complaints was set up as well. Furthermore, Thai government has taken concrete measures to improve Thai tourism practitioners the level of Chinese. Consequently, Thailand has successfully attracted 1.7 million Chinese tourists visiting Thailand in 2011. Thai figure showed that about 7.57 hundred thousand Chinese tourist visited Thailand in the first four months of 2012, and the figure is likely to reach two million in 2012, if in the case, China will surpass Malaysia to be Thai largest tourist country source $^{16}$.

Contracted projects are becoming the important content of trade in service between the two countries. However, it has showed the feature of unilateral. According to source of China's Ministry of Commerce, Chinese enterprises have signed engineering contracts total $\$ 730$ million and completed the US $\$ 460$ million turnover in Thailand in 2010 , while the cumulative total of contracted projects signed by the Chinese enterprises have achieved 7.14 billion US dollars, of which, a turnover of 4.42 billion U.S. dollars has already been completed. China's export of service in Thailand is concentrated in the field of construction ${ }^{17}$.

Financial cooperation or coordination of both sides has already existed and is growing with a strong momentum in the recent years. Thai commercial banks have long had a presence in China to better respond to the needs of their customers in China, namely Bangkok Bank, kasikorn Bank, and Keung Thai Bank. Bank of Thailand is also seeking presence in China. Likewise, Bank of China and Industrial and Commercial Bank of China (ICBC), the two largest Chinese banks, are already operating in Thailand.

With the purpose of strengthening financial cooperation, the Central Banks of the two countries have made significant progress in the field. Bank of Thailand has established a representative office in Beijing in 2011. The Beijing office is Thai first office in Asia and also the first central bank from ASEAN region to have its representative office in China. Since it establishment, Thai Beijing representative office fulfilled its objectives to further promote closer ties between the Bank of Thailand and the People's Bank of China, as well as other Chinese government agencies.

The People's Bank of China and the Bank of Thailand concluded the bilateral local currency swap arrangements during

\footnotetext{
${ }^{16} \mathrm{http} / / /$ world.people.com.cn/GB/157278/17935666.html.

${ }^{17} \mathrm{http} / / /$ hzs.mofcom.gov.cn/aarticle/date/201109/20110907741156.html.
}

the visit of Chinese Vice President Xi Jinping to Thailand in 2001. The Agreement provides for exchange of respective local currency up to 70 billion Yuan or 320 billion Baht, to facilitate bilateral trade and investment. In addition, the Bank of Thailand received approval from People's Bank of China and China Securities Regulatory Commission to participate in the interbank bond market and securities market here in China ${ }^{18}$. Besides, Bank of China Bangkok Branch issued first UnionPay dual-currency debit card (银联双币借记卡) in Thailand in July 2011 to satisfy the needs of both Chinese and Thai people who travel between the two countries ${ }^{19}$.

\section{The Driving Forces and Positive Factors in Boosting the Expansion of Sino-Thai Bilateral Economic Relations}

A painstaking study will find that some driving forces from Below and above are important factors in boosting the advancement of bilateral relations.

\section{Thailand Becomes the Activist in the Building of China and ASEAN Free Trade Area}

The merchants of the two countries are seeking the intra-regional market access due to the eruption of East Asian financial crisis in 1997 and the resurgence of trade protectionism and the shrinkage of FDI from the western countries caused by global economic downturn triggered by the US sub-prime mortgage crisis since 2007, that has become one of the un-neglected driving forces to accelerate the momentum of East Asian regional economic cooperation.

Especially, Thailand becomes the activist in the building of China and ASEAN Free Trade Area (CAFTA) as Thai official and non-official sectors has finally recognized to reaping the benefit form the CAFTA while avoiding the negative impacts. While participating the tracks of tax deduction, namely, Normal Track and The Sensitive Track which were described in Framework Agreement on Comprehensive Economic Co-Operation Between ASEAN and the People's Republic of China, Phnom Penh, 4 November $2002^{20}$, that were further concreted in the other two important agreements ${ }^{21}$, Thai government signed with the Chinese government on June 18, 2003, an "Agreement between the Government of the People's Republic of China and the Government of the Kingdom of Thailand on Accelerated Tariff Elimination under the Early Harvest Pro-

\footnotetext{
${ }^{18}$ Prasarn Trairatvorakul: Economic and Financial cooperation between China and Thailand, Opening remarks by Dr. Prasarn Trairatvorakul, governor of the bank of Thailand, at the Luncheon to inaugurate the bank of Thailand Beijing Representative office, Beijing, 6 April 2012.

${ }^{19}$ In addition to China, the card is accepted by UnionPay's network throughout 110 countries and regions, including Thailand. Any consumption in China will be settled in Renminbi and any consumption in Thailand or other countries and regions will be settled in Thai Baht. Exempting from currency exchange fee, Thai residents, especially those who travel between the two countries, will enjoy such a convenient service.

http://www.boc.cn/en/bocinfo/bi1/201107/t20110721_1472474.html;

http://english.peopledaily.com.cn/102774/7792077.html.

${ }^{20} \mathrm{http}: / /$ www.aseansec.org/13196.htm.

${ }^{21}$ See Protocol to Amend the Framework Agreement on Comprehensive Economic Co-operation between the Assoiation of Southeast Asian nations and the People's republic of China, Bali on October 6, 2003

http://www.aseansec.org/15157. htm; Agreement on Trade in Goods of the Framework Agreement on Comprehensive Economic Co-operation between the Association of Southeast Asian Nations and the People's Republic of China, 29, November 2004. http://www.aseansec.org/16646.htm.
} 
gramme of the Framework Agreement on Comprehensive Economic Cooperation between ASEAN and China", Thailand and China agreed to rapidly eliminate tariffs on fruit and vegetables and other agricultural products over a two-year period from January 2004 to January 2006; tariffs on these products had been totally eliminated. In addition, Tariff reduction under the Early Harvest Program of China and ASEAN covers agricultural goods in the customs tariff schedule codes 01 through $08^{22}$, but Thailand and China have agreed to accelerate tariff reduction on two addition products, anthracite and coal residue.

Although in earlier stage of the "Earlier Harvest Agreement" has caused some problems to the farmers of both sides. This was painful for farmers, particularly those with cooler growing climates similar to China, such as garlic producers in the north of Thailand and Logan producers in Guangxi of China. However, the two governments are still firmly committed to the deal. They have formed a joint working group to survey the problems and obstacles and to enhance information exchange, and in the final have won the win-win situation.

Since CAFTA is entering the second stage from 2011 to 2015, when the other four ASEAN new member states starting the zero tariffs, and the focus of CAFTA will expand to trade of service and market of investment according to the schedule, Thai government has already taken some positive steps and goes ahead of the schedule especially in the financial service.

\section{Closer Contacts of High-Level and Different Levels of Leadership Have Greatly Promoted Bilateral Economic Relations}

Officials from both nations can now praise the excellent state of relations, with frequent reciprocal visits by senior officials of both countries. At height of the relationship, the members of the Thai royal family have made China their frequent destination; especially Her Royal Highness Pricess Maha Chakri Sirindorn has visited China more than three dozen times. In addition, more than 1000 delegates regularly travelled back and forth between the two countries annually since the normalization of diplomatic relations and before the eruption of severe political uncertainty in $2008^{23}$, cementing the Sino-Thai friendship as never before. In March of 2010, HRH Princess Sirindorn was chosen by the Chinese people (in an online poll) as one of the top ten best friends of China. From the Chinese side, President Jiang Zemin, Premier Zhu Rongji and President Hu Jintao paid an official visit to Thailand in 1999, 2001, 2003 respectively. Recently, Vice President Xi Jinping and Chairman Jia Qinglin visited Thailand in December 2011 and April 2012 respectively. Given their importance in fostering relations between the two countries, such visits ensure that this good relationship will always remain strong.

The two countries have also concluded a 23 group of friendly cities and provincial capitals: Beijing-Bangkok (北京市一曼谷 市); Yantai City-Phuket (烟台市 - 普吉府); Kunming-Chiang Mai City (昆明市 - 清迈市); Shanghai-Chiang Mai (上海市 清迈府); Yunnan Province-Chiang Rai (云南省 - 清莱府);

\footnotetext{
${ }^{22}$ Live animals, meat and other edible animal parts, fish products, dairy products, fowl eggs, live trees, vegetables and fruit, and edible nuts.

${ }^{23}$ The recent political instability in Thailand included a bloodless military coup in 2006, the creation of a new constitution and elections in 2007, a political and constitutional crisis in 2008 , and violent government crackdowns on organized protests from 2008-2010. While the long period of instability formally ended with the elections of July 2011, which brought the Pheu Thai Party to power, the political situation remains fragile.
}

Henan Province-Chonburi (河南省 - 春武里府); Nan-ningKhon Kaen City (南宁市 - 孔敬市); the Huludao CityPhetchaburi City (葫芦岛市 - 碧武里市); Guangxi Zhuang Autonomous Region-Surat Thani (广西壮族自治区 - 素叻他 尼府); Wuzhou City-Chanthaburi (梧州市 - 尖竹汶府); Shaanxi Province-Sukhothai (陕西省 - 素可泰府); HainanPhuket (海南省 - 普吉府); Liuzhou0Rayong (柳州市 - 罗勇 府); Beihai City-city of Hat Yai (北海市 - 合艾市); Chaozhou City-Bangkok (潮州市 - 曼谷市); Jieyang City-Lampang City (揭阳市 - 南邦市); Qinzhou City-Tsai Clan House (钦州市 龙仔厝府); Qingdao-Chiang Mai (青岛市 - 清迈府); Harbin City-Chiang Mai (哈尔滨市 - 清迈市); Chongqing CityChiang Mai (重庆市 - 清迈府); Yulin City-North the Lam slope government (玉林市 - 北榄坡府); Dehong Dai and Jingpo Autonomous Prefecture (德宏傣族景颇族自治州 - 达 府); Guangzhou City-Bangkok (广州市 - 曼谷市). Different kinds of delegations from the 23 groups of friendly cities and provincial capitals in particular are frequently exchanged.

\section{“Good Neighboring” Diplomacy Implemented by Chinese Government has Brought about Direct and Positive Implications for Sino-Thai Bilateral Economic Contacts}

At the first ASEAN + 3 summit held in Malaysia in December 1997, China and the Southeast Asian countries agreed to "promote good neighborly and friendly relations, increase highlevel exchanges, strengthen the mechanism of dialogue and cooperation in all areas to enhance understanding and mutual benefit" 24 . Since that time, China has made great efforts to demonstrate its good neighborliness and friendship to the countries of Southeast Asia, including Thailand. China has assisted Thailand under the mutual cooperation of the two countries in several ways and from many aspects that included the efforts of promotion of economic linkages of Thailand and South China, co operations on biotechnology, alternative medicine, and agricultural development, as well as educational development.

To further promote bilateral trade, the two countries have agreed on a Joint Action Plan on Thailand-China Strategic Cooperation which is a five-year cooperative framework for the period 2007-2011. The aim of this Joint Action Plan is to increase trade between the two countries to 50 billion USD by the year 2010. On June 24, 2009 when Mr. Abhisit Vejjajiva, Prime Minister of the Kingdom of Thailand visited China, the two countries have signed an Agreement on Expanding and Deepening Bilateral Economic and Trade Cooperation to further expand and deepen our bilateral economic and trade cooperation, which covers a wide-range of areas of mutual interest, for example agriculture, food, energy, logistics, tourism, restaurants and $\mathrm{SMEs}{ }^{25}$.

When Incumbent Thai Prime Minister Ms. Yingluck Shinawatra paid an official visit to China from 17-19 April this year, the two countries also agreed to establish a comprehensive strategic cooperative partnership. In the Joint Statement of 19 April 2012, the two sides reaffirmed their will to further de-

\footnotetext{
24"JJoint Statement of the Meeting of the Heads of State/Government of the Member States of ASEAN and the President of People's Republic of China" 17th December 1997.

${ }^{25}$ Yang Qi, Obtaining fruitful results with China, Thai PM gained successful visit April 22, 2012

http://news.ynxxb.com/content/2012-4/22/N97950017957.aspx

${ }^{26} \mathrm{http}: / /$ english.gov.cn/2012-04/18/content_2116275.htm.
} 
velop their partnership and solidify cooperation, as well as expressed satisfaction with the state of bilateral relations ${ }^{26}$.

\section{Thai Embassy and Consulates in China Play a Big Role in Marketing Thai Products to China Domestic Market}

Thai embassy in Beijing and consulates in Shanghai, Chengdu, Xian, Xiamen, Guangzhou and Kunming has played a big role in marketing Thai products to China domestic markets. So far as I know the personals from Economic and Commercial Counselor's office are paying much attention and spend a great efforts in conducting China's market survey and research. While assisting Thai merchants to get as more as possible the China's market information, they have taken an actively part in organizing the Thai merchants to attend all kinds of Trade Expos held in China with an aim to introduce Thai products to Chinese consumers. In addition, Thai embassy and consulate have done a wonderful job in helping Thai government to team up with leading department stores and importers from China including City Shop, Carrefour, Lotus Supercenter, Isetan, Metro and Wal-Mart to stage marketing and sales activities in China.

\section{Problems and Future Trend of Sino-Thai Economic Relations}

\section{Problems in Sino-Thai Economic Relations}

Even though much has reaped in the bilateral economic relations between China and Thailand, nevertheless, some problems still existed through in-depth study. Theoretically, there are a lot of rooms for development for "South to South" economic cooperation like the one between China and Thailand, more competitiveness than complementarities however, is existed especially in the trade and investment in term of the similarities of industry structures, hence, some problems are inevitably emerging in the process of the development.

In terms of structures of bilateral trade, some of the major imports and exports of the two countries, as matter of fact, are overlapped. Taking the trade structure of 2010 for example, there were three out of ten products are overlapped (see Tables 3 and 4), namely, while the product of Electronic integrated circuits was listed as the No. 9 in Chinese export to Thailand, which also was the No. 8 in Thai export in China; Electrical equipment and spare parts was listed as the No. 2 in Chinese export to Thailand which also was the No. 10 in Thai export in China; Mechanical equipment and spare parts was listed as No. 3 in Chinese export to Thailand, while No. 1 in Thai export in China. Taking into consideration of the "good neighboring policies" of Chinese government that in many situation demonstrated interference of the state that instructed some stateowned companies to import the goods from Thailand, thus, the question of sustainability will raised.

Since China and Thailand are all absorbing a large amount of foreign investment, and more and more multi-national enterprises (MNEs) and transnational corporations (TNCs) are setting up headquarters in these two countries, therefore, a lot of intro-trade within the branch of companies have produced. Especially for intro-industrial goods containing electronic products, cross borders more than one times, these cost double counting of the trade that accounts for about as high as 30 per cent of the total trade for the trade between the China and
ASEAN in general (Sheng Lijun, 2007; Percival, 2007), and probably the same situation with the trade between China and Thai. Since China and Thailand become in certain degree a kind of "world factory", and the automobile production base of all kinds of brand or logo, hence, computer equipment and parts, automatic data processing equipment and parts, mechanical equipment and spare crossing border of the two countries frequently are as matter of fact the intro trade within the MNEs or TNCs which benefit more to the foreign investors than to the people of the two countries.

Complicated reasons caused the bilateral investments far behind bosh sides' expectation. The major constrains can be described from the perspectives of politically, economically and culturally.

From China's perspective, the instability of Thai political situations started since 2006 was the first major barrier for Chinese investor to invest Thailand in consideration of the risks. Besides, Thai economic situation are also un-favorable to Chinese investment as Thailand was the center of East Asian financial crisis, and the economy was under the constrains of IMF load's condition, that resumed its recovery only for several years since 2003 before it caught in political unrest in 2006 . Moreover, the relatively poor investment environment is also an important reason to prevent the Chinese investors to invest in Thailand, such as higher wage rates or the labor turnover ${ }^{27}$, different labour employment system as well as labor laws and regulation, and the prices of raw materials and components are much higher than those in China (Sompop, 2009).

The Thai investors have also encountered obstacles while investing in China. Above all, the shortage of qualified executives with good language, thence, Thai companies investing China have to hire the one from the other countries, not only add the cost, but also cause some unloyalty problems. In addition, Thai investor are facing business network barriers as their counterparts do in Thailand, as many of small and mediumsized companies could not get access deep to the Chinese business circles to build up business network.

Though China's vast domestic market absorbs a large amount of Thai agro-products ascribing to the introduction of the "Earlier Harvest", Nevertheless, because some of special product like fruits and vegetables having the features of seasonal, not easy storage, and lacking flexibility of market demand and etc., very often the vegetable farmers and fruit farmers of both sides are suffering form lacking of the market information, as a result, their produce unsalable due to the market saturation.

\section{Future Trend of Sino-Thai Economic Relations}

According to the agenda, the building of CAFTA has to undergo three stages, taking about another one decade. The first stage was from 2002 to 2010; the second stage is from 2011 to 2015, when the other four ASAEN new member states starting the zero tariffs and the focus of CAFTA will expend to trade of service and market of investment. The third stage is after 2016, and CAFTA will continue to be more consolidated and perfect. China and ASEAN-10 have signed the "Second Protocol to Amend the Agreement on Trade in Goods of the Framework Agreement on Comprehensive Economic Co-Operation be-

\footnotetext{
${ }^{27}$ In Thailand, wage rates are usually about $30-50 \%$ higher than in China. ${ }^{28} \mathrm{http} / /$ www.aseansec.org/documents/acfta/2nd-Protocol-to-Amend-the-TI G-CTC.pdf.
} 
tween the Association of Southeast Asian Nations and the people's Republic of China" in Kuala Lumpur, the capital of Malaysia on October $29,2010^{28}$.

Global economic meltdown and the re-emergence of global trade protectionism have once again highlighted the importance of regional economic cooperation.

There are complementarities between China and Thailand economically ascribing to the features of diversities of these two countries in the empowerment of natural resources, economic development stage, and the public consumption. Since the governments of the two countries have recognized the importance of the further economic cooperation are in the benefit of the people welfare, and many effective initiatives are being adopted in particular in the form of seminars, study visits, program training cooperation projects and Est., that can greatly improve both sides to understand each other's political, economic and cultural situation. Moreover, the coordination of the two governments are going on so far smoothly, there are good reasons to trust that the relationship between China and Thailand in the next five years will be further enhanced.

\section{REFERENCES}

Percival, B. (2007). The dragon looks south: China and Southeast Asia in the new century. USINO Breef. URL (last checked 30 May 2009). http://www.usindo.org

Sheng, L. J. (2007). Forty years of ASEAN: Relations with chin. International Conference of "ASEAN 40 Years: Review and Prospect", Beijing: Peking University, 15th-17th November.

Shen, H. F. (2010). China-Southeast Asian economic relations in the 21 st century: Evolving features and future challenges. International Journal of China Studies (Malaysia), 1, 25-45.

Shen, H. F. (2011). Different voices under China-ASEAN free trade area: An exploration. China-ASEAN Integration \& Trade Journal (Malaysia), 1, 17-42.

Sompop, M. (2009). Thailand-China cooperation in trade, investment and official development assistance. URL (last checked 20 July 2012).

http://www.ide.go.jp/English/Publish/Download/Brc/pdf/01_thailand andchina.pdf

Wang, Y.-Z. (2012). "The impact of CAFTA on China-ASEAN relationship: An evaluation from strategic perspective. Southeast Asian Affairs (Xiamen), 1, General Serial No. 149, 9-20.

Wang, Q. (2011). Two decades of China-ASEAN economic relations: Retrospect and prospect. Southeast Asian Affairs (Xiamen), 4, General Serial No.148, 20-26. 